\title{
The Effect of ICT Assisted Project Based Learning Approach on Prospective ICT Integration Skills of Teacher Candidates
}

\author{
Pusat Pilten ${ }^{1}$, Gulhiz Pilten ${ }^{2}$, Nihan Sahinkaya ${ }^{3}$ \\ ${ }^{1}$ Akhmet Yassawi University, Faculty of Human Sciences, Turkistan, Kazakhystan \\ ${ }^{2}$ Necmettin Erbakan University, Ahmet Kelesoglu Faculty of Education, Meram, Konya, Turkey \\ ${ }^{3}$ Istanbul Medeniyet University, Faculty of Educational Science, İstanbul, Turkey \\ Correspondence: Pusat Pilten, Akhmet Yassawi University, Faculty of Human Sciences, Turkistan, Kazakhystan.
}

Received: December 6, 2016

Accepted: February 3, 2017 Online Published: February 17, 2017

doi:10.11114/jets.v5i3.2051

URL: https://doi.org/10.11114/jets.v5i3.2051

\begin{abstract}
The purpose of the present research is studying the effects of information and communication technologies (ICT) assisted project based learning practices on ICT integration skills of pre-service classroom teachers. The research adopted a mixed method. The quantitative dimension of the research was designed with pre-test-post-test control groups. The qualitative dimension was conducted as a case study. The work group of the research consisted of 72 pre-service teachers, who studied at the third grade of the department of the classroom teaching of a state university in the province of Konya in 2015-2016 academic year; 34 of the participants were included in the experiment group and 38 were included in the control group. ICT Self-Efficacy Perception Scale (ICT-SEPS) and ICT Attitude Scale (ICT-AS) used as the quantitative data collection tools for the present research were obtained from the literature. The interview form used to collect the qualitative data of the research was developed by the researchers in accordance with the related literature. Comparison of the data collected before and after the 12-week experimental procedure revealed that ICT assisted project based learning practices had positive effects on ICT self-efficacy perceptions and attitudes and accordingly expected ICT integration levels among pre-service teachers.
\end{abstract}

Keywords: ICT, ICT-teaching integration, pre-service classroom teachers

\section{Introduction}

The concept of Information and Communication Technologies (ICT) focuses on communication, decision making and problem solving skills and is defined as processes, tools and techniques for (1) gathering and identifying information; (2) classifying and organizing; (3) summarizing and synthesizing; (4) analysing and evaluating; and (5) speculating and predicting (Alberta Learning, 2002).

In this context, ICT can be defined as a concept that gathers the information technologies and communication technologies related concepts under one concept and emphasizes the relations between these technologies (OECD, 2006). The above-mentioned definitions are generally explained in three interrelated categories in the literature. The first category- communicating, inquiring, decision making and problem solving- includes skills related to the, accessing information through criticising, solving problems, communicating with the resources in accordance with these objectives, and managing and conducting a research. The skills included in this category expect students to use their knowledge and skills in real life situations. The second category-foundational operations, knowledge and concepts in technology- includes the nature of technology and its effects, ethical use of the technology, mass communication tools in digitized context, ergonomic and safety issues, and basic computer, telecommunication and multi-media operations. The third category - processes for productivity- refers to the ability to use basic production tools and techniques to compose texts, organize data, compose and manipulate graphics, audio and multimedia, integrate the media with teaching processes, use electronic communication systems, cooperate electronically, share location and navigate (Alberta Learning 2002).

\subsection{Integration of ICT with Learning-teaching Environments}

Educational dimension of ICT can be studied in many dimensions. For instance Godfrey (2001) states that ICT should be integrated with teaching for it provides a rich learning environment, forms the skill of developing a 
multi-dimensional perspective related to a complex phenomenon for the students, supports a flexible information structuring for complex learning contents and meets different needs resulting from individual differences.

Additionally, students can learn how information is accessed and organized in a very effective way as they learn how to use ICT, as it requires an active research. In this context, ICT is very important and necessary for the transformations expected from learning environments, for it provides opportunities for transforming traditional teacher centred practices into student centred environments and also environments for sharing and cooperation (Papanastasiou \& Angeli, 2008).

Marcinkiewicz (1993) stated that for a successful integration of ICT with education, an agreement between technology and teachers is required. This should start at teacher training process. Roblyer (2002) states that many pre-service teachers have low levels of computer knowledge and attitudes towards the use of ICT in classroom environments when they start university. This situation doesn't change during their education, and accordingly when pre-service teachers complete their education, they aren't ready to integrate technology to education-teaching processes (Bielefeldt, 2001; Willis \& Montes, 2002; Doering, Hughes \& Huffman, 2003; Wang, Ertmer \& Newby, 2004). Moreover, it was found that most pre-service teachers weren't willing for this integration (Mumtaz, 2000; Baylor \& Ritchie, 2002). Others, who are willing, are mostly unsuccessful in integrating technology in education-teaching processes for they cannot find good models during their education (Breen et. al., 2001; Iding et al., 2002).

For these reasons, the quality of education on the integration of educational technologies with learning and teaching practices in teacher education has been discussed frequently since education technologies entered in classroom environments (Krueger, Hansen, \& Smaldino, 2000). According to the related literature, one of the effective tools that enable the use of ICT in accordance with a curriculum is ICT-assisted project based approach. Simpson (2010) provides the steps of PBL, which include project start, development, report, and assessment. He explains that, "Starting the project involves selecting the topic that is of interest and relevance to students. The teacher can create guiding questions ... The project should be challenging and motivating such that students can develop and have the flexibility to work at their own level. Then, Project development involves the research, which is undertaken by all group members either individually, in pairs, or as a group. This should be decided by the group before commencing the project. Reporting to the class involves presenting and receiving feedback from other students. Lastly, assessment is when the final product is evaluated by an individual student, students as a group or a teacher." (pp. 58-59)

In the project based teaching practices defined above, ICT is especially effective in the steps of communication, accessing, organizing and presenting information. Besides, it has a significantly enabling role in practices based on student-teacher cooperation (Moursund, 2002). At this point, there are some issues that should be taken into consideration in the supporting of project based learning environments with ICT (Donnelly \& Fitzmaurice, 2005):

- Bringing exciting curricula based on real-world projects into the classroom;

- Providing scaffolds, tools and resources to enhance learning;

- Giving both students and teachers more opportunities for feedback, and reflection;

- Expanding opportunities for student learning through collaboration and discussion.

The related literature emphasizes the importance of the teacher factor in the process of integration teaching environments with ICT, which includes many different dynamics and should be studied multi-dimensionally. The proliferation and application of educational innovations mostly depend on the personal and individual meanings attached to those by teachers, in other words, the adoption of these innovations by teachers (Becker, 2001). Indeed, research has proven that teachers create their own principles, ideas and judgements about the use of ICT in the classrooms, and all these affect their practices (La Velle, McFarlene, Brawn, 2003). Sung (2007) presented a model for integration. This model claims that ICT integration expected from pre-service teachers consists of five variables, that interact with each other (Figure 1).

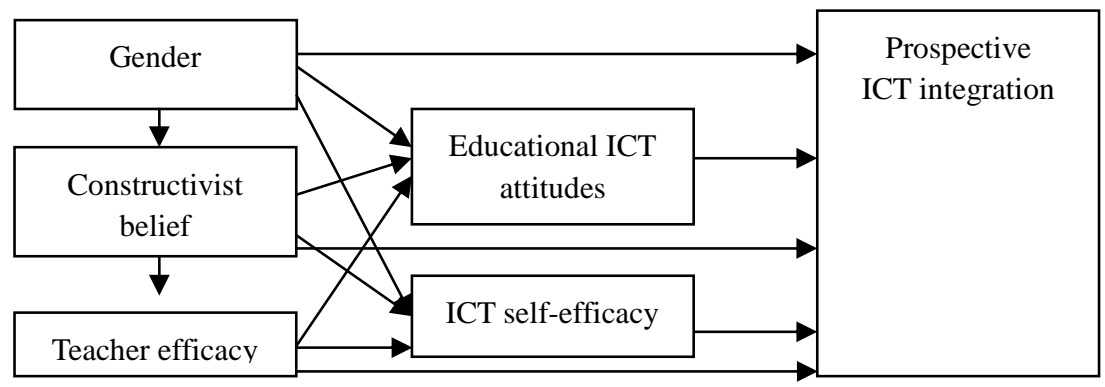

Figure 1. Pre-service teachers' processes of thinking on prospective ICT integration

As presented in Figure 1, gender, constructivist belief and teacher efficacy form pre-service teachers' educational ICT 
attitudes and ICT self-efficacy perceptions, and these two variables form their prospective ICT integration skills. Bandura (1986) defines the concept of self-efficacy as individuals' beliefs and judgements on their efficacies in achieving a task (Cassidy \& Eachus, 2002). Bandura's socio-cognitive theory helps us provide a conceptual framework that can define ICT self-efficacy perception. In this context, there are 4 main factors that identify self-efficacy (Magliaro \& Ezeife, 2007): (1) performance accomplishments; (2) vicarious experiences; (3) verbal persuasion and (4) emotional arousal. For the present research, ICT assisted project based learning approach, which is related to all four factors on the development of ICT self-efficacy perception listed above, was adopted.

As presented in Figure 1, another factor affecting the integration of ICT with teaching is attitudes towards ICT. Fishbein and Ajzen (1975) define attitude as negatively or positively learnt tendencies for an object, phenomenon or person. With the expanding use of technology at school environments in recent years, the attitudes of educators towards the integration of ICT with teaching environments have been frequently studied by researchers in recent years (Jimoyiannis \& Komis, 2007; Wen \& Shih, 2008). The findings of those researches show that educators mostly present negative attitudes on this issue (Todman, 2000).

Another finding presented in Figure 1 is that an individual's self-efficacy perceptions and attitudes towards ICT can explain their perspectives of the integration of ICT with teaching environments. The related literature includes many studies on the levels of the individuals in the process of the integration of ICT with teaching environments. Some of these are presented in Table 1.

Table 1. ICT-teaching environments integration levels

\begin{tabular}{|c|c|c|c|c|}
\hline Stage & Rogers & CEO Forum & Gladhart & Russell \\
\hline 1 & Knowledge & Entry & Entry & Awareness \\
\hline 2 & Persuasion & Adoption & Adoption & Learning the process \\
\hline 3 & Decision & Adaptation & Adaptation & $\begin{array}{l}\text { Understanding and application } \\
\text { of the process }\end{array}$ \\
\hline 4 & Implementation & Appropriation & Appropriation & Familiarity and confidence \\
\hline 5 & Confirmation & Invention & Invention & Adaptation to other contexts \\
\hline 6 & & & & $\begin{array}{l}\text { Creative application to new } \\
\text { contexts }\end{array}$ \\
\hline
\end{tabular}

Table 1 presents a comparison of different levels included in different studies. All of these actually have similarities at many levels. CEO Forum's and Gladhart's models addressed the issues of teacher behavior, student behavior, and technology tools regarding computer integration. The teacher behavior part of the model lists the following five levels of computer technology integration: entry, adoption, adaptation, appropriation, and invention.

The purpose of the present research is defining the effects of ICT assisted project based learning approach on pre-service teachers' levels of integrating ICT with educational environments. In accordance with this purpose, the present research tries to define ICT self-efficacy perceptions and ICT attitudes that source the levels of ICT-educational environments integration, along with their levels of ICT-educational environments integration. A mixture of quantitative and qualitative methods was adopted for this purpose.

The problem statement of the research is "Do Information and Communication Technologies assisted project based learning applications have significant effects on pre-service teachers' perceptions of integration of ICT with teaching environments, within the scope of "Turkish Language" and "Mathematics Teaching I" courses?" With this purpose, the answers to the following questions are sought:

Are there any significant differences between the pre-service teachers in the experiment group, who took "Turkish Language Teaching" and "Mathematics Teaching I" courses in their undergraduate program in accordance with the information and communication technologies assisted project based learning approach and the pre-service teachers in the control group, on who this method wasn't implemented;

1. in terms of ICT self-efficacy perceptions before the experimental procedure?

2. in terms of the attitudes towards ICT before the experimental procedure?

3. in terms of ICT self-efficacy perceptions after the experimental procedure?

4. in terms of the attitudes towards ICT after the experimental procedure?

5. in terms of the kind of changes occurred before and after the experimental procedure in their levels of ICT-educational environments integration?

\section{Method}

\subsection{Research Design}

The present research, which was conducted in order to define the effects of ICT assisted project based learning practices 
on students' perceptions of integration of ICT with learning environments, adopted a mixed method. According to mixed method, research problems can be understood with not only quantitative or qualitative method alone, but when both are used together (Creswell and Plano-Clark, 2007). The present research adopted a design suggested by Steckler et al. (1992), which used quantitative and qualitative data equally and in parallel with each other (Figure 1).

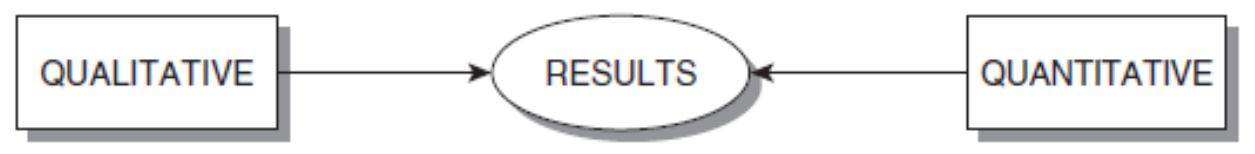

Figure 2. Research Design

The design presented in Figure 1 was implemented by successively adding up the quantitative data collected to reveal the effects of ICT assisted project based learning practices on pre-service teachers' perceptions of and attitudes towards ICT and the qualitative data collected to define pre-service teachers' levels of integrating ICT with teaching environments.

The quantitative dimension of the present research, which aims at studying the effects of ICT assisted project based learning practices of pre-service teachers' ICT self-efficacy and attitudes, was designed in pre-test-post-test experiment model with control group. Table 2 present the experimental design used in the present research with symbols.

Table 2. Experimental design used in the research

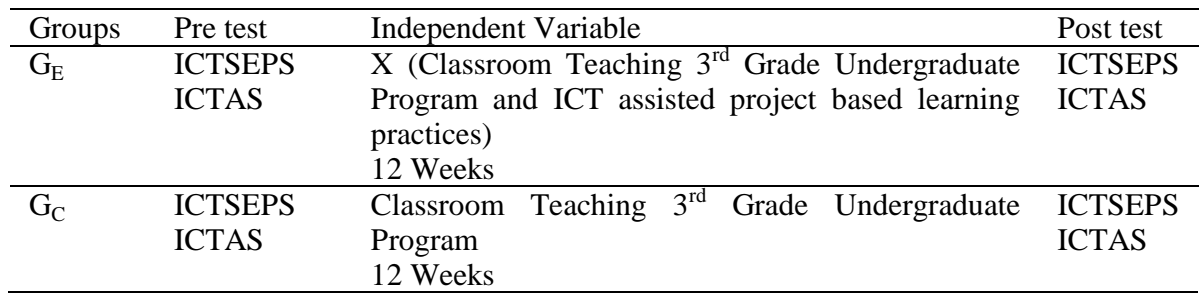

In Table $2 \mathrm{G}_{\mathrm{E}}$ stands for experiment group, $\mathrm{G}_{\mathrm{C}}$ for control group, ICTSEPS (ICT Self-Efficacy Perception Scale) and ICTAS (ICT Attitude Scale) stand for pre-test and post-test measurements of experiment and control groups; and X stands for the independent variable implemented on experiment group participants (ICT assisted project based learning practices with Classroom Teaching $3^{\text {rd }}$ Grade Undergraduate Program). Additionally, Table 1 shows that teaching practices used in experiment and control groups lasted for 12 weeks.

The qualitative dimension of the present research, which aims at investigating the effects of ICT assisted project based learning practices on pre-service teachers' levels of integrating ICT with teaching environments is designed as a case study. The only case studied in the present research is pre-service teachers' levels related to the integration of ICT with teaching environments. Within the present research, pre-service teachers, whose levels related to integration were defined were taken as a unit of analysis.

\subsection{Participant Characteristics and Sampling Procedures}

Work group of the present research consists of 72 university students, who studied at the $3^{\text {rd }}$ grade of the department of Classroom Teaching at one of the state universities in Turkey in 2015-2016 academic year. Of these students, 34 were included in the experiment group and 38 were included in control group. The state university, where the students included in the work group was selected due to convenient sampling reasons. For the present research, this method was adopted due to the length of experimental procedure and the necessity to interview the participants out of the classes. The participants were selected for experiment and control groups among the $3^{\text {rd }}$ grade students of the mentioned state university through random sampling method. Some features of the students included in the work group are presented in Table 3.

As presented in Table 3, experiment and control groups are distributed similarly by gender. The numbers of students included in experiment and control groups can also be considered similar. After the work groups were determined, the students in the experiment groups were informed about the content of the research. They were given information about the relation between the research and the course content, its importance in this content, its place in the present primary school curriculum, and for what reason the findings of the research will be used. The students were informed that participation wasn't compulsory but that the participation was important in terms of the attainments of the related courses. After this information, all of the students participated in the research voluntarily. 
Table 3. Characteristics of experiment and control groups

\begin{tabular}{llllllllllll}
\hline \multirow{2}{*}{ Groups } & \multicolumn{1}{l}{ Gender } & \multicolumn{1}{l}{ Age } & \multirow{2}{*}{ Total } \\
& \cline { 2 - 13 } & Female & Male & 21 & 22 & & \\
& f & $\%$ & f & $\%$ & f & $\%$ & f & $\%$ & f & $\%$ & \\
\hline Experiment & 34 & 80.95 & 8 & 19.05 & 6 & 14.29 & 21 & 50 & 15 & 35.71 & 42 \\
\hline Control & 38 & 84.44 & 7 & 15.56 & 4 & 8.89 & 27 & 60 & 14 & 31.11 & 45 \\
\hline
\end{tabular}

During the research process, 3 different data collection tools were used (ICT Self-Efficacy Perception Scale, ICT Attitude Scale and Integration Level Interview Form). The groups and the number of students, on which these data collection tools were implemented, are presented in Table 4.

Table 4. Groups and the number of students, on which data collection tools were implemented

\begin{tabular}{lllllll}
\hline Groups & \multicolumn{9}{l}{ Scales and Number of Students } & & \\
\cline { 2 - 7 } & $\begin{array}{l}\text { ICT } \\
\text { Perception Scale }\end{array}$ & $\begin{array}{l}\text { Self-Efficacy } \\
\end{array}$ & ICT Attitude Scale & \multicolumn{2}{l}{$\begin{array}{l}\text { Integration } \\
\text { Interview Form }\end{array}$} & Level \\
\cline { 2 - 7 } & f & $\%$ & f & $\%$ & f & $\%$ \\
\hline Experiment & 34 & 100 & 34 & 100 & 9 & 27,47 \\
\hline Control & 38 & 100 & 38 & 100 & 10 & 26,32 \\
\hline
\end{tabular}

As presented in Table 4, ICT self-efficacy perception scale and ICT attitude scale were implemented on all students in the experiment and control groups, while the integration level interview form was limited to 9 students in the experiment group and 10 students in the control group. Integration level interview form was implemented only after the experimental procedure and the participants for the interviews were selected randomly among the students between the upper (27\%) and lower (27\%) score range in terms of their self-efficacy perception and attitude scores.

\subsection{Data Collection Tools}

Data collection tools used in the present research are as follows:

ICT Self-Efficacy Perception Scale (ICTSEPS): In order to measure pre-service classroom teachers ICT self-efficacy perceptions, "ICT Self-Efficacy Perception Scale" developed by Ekici et al. (2012) for teachers was used as pre-test and post-test. The scale consists of 27 items scores on a 5-point likert type scale. Higher scores from the scale indicate higher perceptions related to ICT self-efficacy. According to the analyses conducted by the researchers, the scale has a single dimensional structure and the cronbach alpha reliability coefficient was calculated as .97 . In order to calculate the cronbach alpha reliability coefficient for the present research, a trial implementation was conducted on 141 students, studying at the $3^{\text {rd }}$ grade of classroom teaching department of a different state university, and the coefficient was calculated as .86. Additionally, test-retest reliability method was used to present the consistency of the scale based on time factor. Trial implementation was repeated with the 141 students mentioned above 4 weeks later, and the Pearson product-moment correlation coefficient between the scores obtained from two implementations was calculated as .81.

ICT Attitude Scale (ICTAS): In order to measure the ICT attitudes of the pre-service classroom teachers for the present research, "ICT Attitude Scale" developed by Hismanoglu and Hismanoglu (2011) was used. The scale consists of 9 items scored on a 5-point likert type scale. According to the analyses conducted by the researchers, the scale has a single dimensional structure and the cronbach alpha reliability coefficient was calculated as .90 . In order to calculate the cronbach alpha reliability coefficient for the present research, a trial implementation was conducted on 141 students, studying at the $3^{\text {rd }}$ grade of classroom teaching department of a different state university, and the coefficient was calculated as .83. Additionally, test-retest reliability method was used to present the consistency of the scale based on time factor. Trial implementation was repeated with the 141 students mentioned above 4 weeks later, and the Pearson product-moment correlation coefficient between the scores obtained from two implementations was calculated as .88.

Integration Level Interview Form (ILIF): Some of the participants from experiment and control groups were selected randomly, and these participants were interviewed using the semi-structured integration level interview form (ILIF) developed by the researchers. With the interviews, the researchers tried to collect data related to the pre-service teachers' ideas on (1) the place and purpose of ICT within teaching process; (2) the role and efficacy of the teachers in the process. Semi-structured interview form consists of 5 open-ended questions aimed at explaining 2 items mentioned above. The draft of the interview form was studied by 6 faculty members of Classroom Teaching Departments in Turkey, and some revisions were done.

\subsection{Data Analysis}

Quantitative data collected for the present research were analysed on SPSS 19.0 packaged software. In order to determine the statistical technique to be used, all data collected from the dependant variable (ICTSEPS and ICTAS) were tested for normality with Kolmogorov-Smirnov test ( $\mathrm{p}>.05)$. According to the normality tests, scores obtained from both scales distributed normally, therefore independent samples t-test of parametric hypothesis tests was selected for analyses. 
Qualitative data obtained with interviews were analysed with descriptive analysis method. That the conceptual structure related to the research question can be presented clearly beforehand is the most basic factor in selecting the descriptive analysis method. The interviews were carried by the researchers. After the interviews were completed, data recorded during the interviews with pre-service teachers were transcribed. This procedure was followed by coding procedure. During the coding of the data, the researchers studied the collected data, and tried to separate these data into meaningful parts and to find out what each part meant conceptually. These parts presenting a meaningful consistency within were named by the researchers. This way, the researchers tried to find a concept that can best describe the meaning of the related part as they coded a meaningful part. For the present research, "coding in accordance with the concepts inferred from the data" type of coding was adopted, as the related literature didn't include any code lists on the subject matter of the present research.

The present research also tried to realize "triangulation", which is considered as another method for providing validity and reliability in the literature, and refers to researcher variation based on the studying of any case by different researchers at the same time. For this purpose, individuals, who had general knowledge on the subject matter of the present research and competency in qualitative research methods, were asked to study the research from various dimensions in order to take necessary measures to increase the quality of the research. With this purpose, the problem case suggested by at least one of the experts were presented to other experts and the research process was re-arranged in accordance with the common opinions of the experts.

\subsection{Experimental Manipulations or Interventions}

The qualities of the ICT assisted projects prepared by the students in the scope of "Turkish Language Teaching" and "Mathematics Teaching" courses used in the experimental procedure of the present research, are presented below.

Projects for Turkish Language Teaching Course: Turkish-Project 1 (TP1): The students were asked to create a digital storytelling and an interactive educational CD-ROM for evaluating the comprehension of a text presented in this way at primary education level. Time allocated for the project was 3 weeks. The elements that the students should take into consideration were: (1) digital story elements (point of view, dramatic question, emotional context, soundtrack, economy, pacing, voice), (2) instructional content, (3) curriculum connections, (4) graphics/multimedia, (5) layout, (6) technical aspects, (7) engagement/interactivity, (8) assessment, (9) age/grade appropriateness, (10) upper level cognitive questions (analysis, synthesis, assessment, etc.), (11) question type (in text, out of text, inter texts questions), (12) metacognitive questions.

Turkish-Project 2 (TP2): The students were asked to shoot a short film to support the subject of visual reading included in primary school Turkish teaching program. Time allocated for the project was 3 weeks. The elements that the students should take into consideration were: (1) content/organization, (2) video continuity/editing, (3) audio editing, (4) lighting, (5) camera techniques (exposure/focus), (6) and timing.

Projects for Mathematics Teaching Course: Mathematics-Project 1 (MP1): Students were asked to create an interactive educational CD-ROM to teach and enrich the content of the fractions subject included in primary school mathematics teaching program. Time allocated for the project was 3 weeks. The elements that the students should take into consideration were: (1) instructional content, (2) curriculum connections, (3) graphics/multimedia, (4) layout, (5) technical aspects, (6) engagement/interactivity, (7) assessment, (8) age / grade appropriateness.

Mathematics-Project 2 (MP2): The students were asked to shoot a short film to teach the subject of fractions included in primary school mathematics teaching program. Time allocated for the project was 3 weeks. The elements that the students should take into consideration were: (1) content/organization, (2) video continuity/editing, (3) audio editing, (4) lighting, (5) camera techniques (exposure/focus), (6) and timing.

Experimental procedure started in the $7^{\text {th }}$ week of the fall semester of 2015-2016 academic year, and projects MP1, MP2, TP1 and TP2 were carried respectively. Projects TP1 and TP2 were carried in the spring semester of the same academic year. In class activities repeated for each project were as follows:

Introduction to the Project Week ( $1^{\text {st }}$ Session): Groups of 4-5 students were formed; Project was introduced to the students; Project groups were given some time for distribution of tasks; Project groups were given some time to create project drafts; Project groups were given some time to present their drafts to other groups; Project groups were asked to provide other groups with feedback about their drafts; Students were asked to define the activities they would conduct within the scope of their projects until the following week; The students were asked to fill in and bring along the "Weekly Project Evaluation Form" for the next session to systematize their studies for the following weeks.

Project Enrichment Weeks ( $2^{\text {nd }}$ and $3^{\text {rd }}$ Sessions): Each group was asked to present the activities they conducted within the past week in accordance with the "Weekly Project Evaluation Form"; Project groups were asked to provide other groups with feedback about the activities they conducted during the past week; The groups submitted their weekly 
project evaluation forms; The groups were given some time to plan their following week.

Project Conclusion Week ( $4^{\text {th }}$ Session): Students submitted their projects and project conclusion reports; $4^{\text {th }}$ session for each project was also the introduction to the project week ( $1^{\text {st }}$ session) for the following project.

\section{Findings and Interpretations}

In this part, findings related to collected quantitative and qualitative data are studied separately in relation to the sub-problems.

\subsection{Comparison between Experiment Group and Control Group Students on ICTSEPS-ICTAS Pre-and Post-test Results}

T-test analyses were conducted for the independent groups in order to answer the research question "Are there any significant differences between the pre-service teachers in the experiment group, who took "Turkish Language Teaching" and "Mathematics Teaching I" courses in their undergraduate program in accordance with the ICT assisted project based learning approach and the pre-service teachers in the control group, on who this method wasn't implemented in terms of ICT self-efficacy perceptions and attitudes towards ICT before the experimental procedure?" Analysis results are presented in Table 5 and Table 6.

Table 5. T-test results for the ICTSEPS and ICTAS pre-test scores of experiment and control group students

\begin{tabular}{|c|c|c|c|c|c|c|c|}
\hline Scale & Group & $\mathrm{N}$ & $\bar{X}$ & $\mathrm{~S}$ & sd & $\mathrm{t}$ & $\mathrm{p}$ \\
\hline \multirow{2}{*}{ ICTSEPS } & Experiment & 34 & 74.85 & 14.85 & \multirow{2}{*}{70} & \multirow{2}{*}{1.166} & \multirow{2}{*}{.247} \\
\hline & Control & 38 & 70.79 & 12.68 & & & \\
\hline \multirow[t]{2}{*}{ ICTAS } & Experiment & 34 & 27.06 & 4.15 & \multirow{2}{*}{70} & \multirow{2}{*}{1.36} & \multirow{2}{*}{.178} \\
\hline & Control & 38 & 29.85 & 7.88 & & & \\
\hline
\end{tabular}

According to the findings presented in Table 5, there aren't any statistically significant differences between experiment and control group students in terms of ICTSEPS pre test scores [t=1,166, $\mathrm{p}>.05]$. This finding indicates that there weren't any significant differences between groups in terms of ICT self-efficacy perceptions before the experimental procedure. In other words, according to ICTSEPS pre test scores, the groups were equal in terms of ICT self-efficacy perceptions.

Another finding presented in Table 5 is that, experiment groups students' ICTAS pre-test score average $(27,06)$ was lower than control group students' attitude score average $(29,85)$, even slightly. This significance of this difference was tested with t-test, and according to the results there aren't any significant differences between groups in terms of their ICTAS pre-test scores [ $t=1.36 ; \mathrm{p}>.05]$. In other words, experiment and control groups were equal in terms of their ICT attitudes before the experimental procedure.

T-test analyses were conducted for the independent groups in order to answer the research question "Are there any significant differences between the pre-service teachers in the experiment group, who took "Turkish Language Teaching" and "Mathematics Teaching I" courses in their undergraduate program in accordance with the ICT assisted project based learning approach and the pre-service teachers in the control group, on who this method wasn't implemented in terms of ICT self-efficacy perceptions and attitudes towards ICT after the experimental procedure?" Analysis results are presented in Table 6.

Table 6. T-test Results for the ICTSEPS and ICTAS post-test scores of experiment and control group Students

\begin{tabular}{|c|c|c|c|c|c|c|c|}
\hline Scale & Group & $\mathrm{N}$ & $\bar{X}$ & $\mathrm{~S}$ & $\mathrm{sd}$ & $\mathrm{t}$ & $\mathrm{p}$ \\
\hline \multirow[t]{2}{*}{ ICTSEPS } & Experiment & 34 & 98.15 & 15.04 & \multirow{2}{*}{70} & \multirow{2}{*}{6.652} & \multirow{2}{*}{.000} \\
\hline & Control & 38 & 74.66 & 14.89 & & & \\
\hline \multirow[t]{2}{*}{ ICTAS } & Experiment & 34 & 40.97 & 2.41 & \multirow{2}{*}{70} & \multirow{2}{*}{12.05} & \multirow{2}{*}{.000} \\
\hline & Control & 38 & 29.85 & 5.16 & & & \\
\hline
\end{tabular}

According to the findings presented in Table 6, there is a significant difference between experiment and control groups in terms of their ICTSEPS post-test scores, in favour of the experiment group [ $t=6,652, p>.05]$. This finding suggests that experimental procedures conducted with the experiment group had positive effects on students' ICT self-efficacy perceptions. In other words, according to ICTSEPS post-test scores, ICT assisted project based learning practices conducted with the experiment groups developed students' ICT self-efficacy perceptions more than the control group practices at a statistically significant level.

Another finding presented in Table 6 is that, experiment groups students' ICTAS post-test score average $(40,97)$ was higher than control group students' attitude score average $(29,85)$, even slightly. This significance of this difference was tested with t-test, and according to the results there was a significant difference between ICTAS post-test score averages, in favour of experiment group students [t=12.05; $\mathrm{p}>.05]$. In other words, according to ICTAS post-test scores, ICT assisted project based learning practices conducted with the experiment groups developed students' attitudes towards ICT more than the control group practices at a statistically significant level. 


\subsection{Findings and Interpretations Related to Qualitative Data}

Collected qualitative data were used to answer ICT integration into education stage related sub-problem of the research; "Are there any significant differences between the pre-service teachers in the experiment group, who took "Turkish Language Teaching" and "Mathematics Teaching I" courses in their undergraduate program in accordance with the information and communication technologies assisted project based learning approach and the pre-service teachers in the control group, on who this method wasn't implemented in terms of the kind of changes occurred before and after the experimental procedure in their levels of ICT-educational environments integration? The procedures followed to answer this question and the obtained findings are presented below.

3.2.1 Findings Related to the Pre-service Teachers' Teaching ICT Integration Levels before and after the Experimental Procedure

Before and after the experimental procedure, interviews were done with 9 experiment group and 10 control group pre-service teachers selected randomly before the experimental procedure, and the data explaining the estimated integration levels related to the place and purpose of ICT in the teaching process are presented in Table 7.

Table 7. Estimated ICT integration levels of pre-service teachers in terms of the place and purpose of ICT in the teaching process

\begin{tabular}{|c|c|c|c|c|c|c|}
\hline \multirow[t]{3}{*}{ Category } & \multirow[t]{3}{*}{ Sub Category } & \multicolumn{2}{|c|}{$\begin{array}{l}\text { Before the } \\
\text { Procedure }\end{array}$} & \multicolumn{2}{|c|}{$\begin{array}{l}\text { After the } \\
\text { Procedure }\end{array}$} & \multirow{3}{*}{ E.I.L. } \\
\hline & & $\begin{array}{l}\text { Exp. } \\
\text { Group }\end{array}$ & $\begin{array}{l}\text { Control } \\
\text { Group }\end{array}$ & $\begin{array}{l}\text { Exp. } \\
\text { Group }\end{array}$ & $\begin{array}{l}\text { Control } \\
\text { Group }\end{array}$ & \\
\hline & & f $\%$ & f $\%$ & $\mathrm{f} \quad \%$ & f $\%$ & \\
\hline \multirow{7}{*}{$\begin{array}{l}\text { The place } \\
\text { and purpose } \\
\text { of ICT in } \\
\text { the teaching } \\
\text { process }\end{array}$} & Personal use & 4 & 3 & 1 & 3 & 1 \\
\hline & Used to develop their own productivity & 2 & 4 & 1 & 3 & 2 \\
\hline & $\begin{array}{l}\text { Used in a way to ease the traditional } \\
\text { practices }\end{array}$ & 3 & 2 & 2 & 3 & 2 \\
\hline & Used in association with curriculum & & 1 & 2 & 1 & 3 \\
\hline & Used for lesson presentations & & & 1 & & 3 \\
\hline & Used as resource & & & 1 & & 3 \\
\hline & Used to develop learning & & & 1 & & 4 \\
\hline
\end{tabular}

As presented in Table 7, in terms of the place and purpose of ICT in the teaching process, the responses of pre-service teachers show that they mostly prefer using ICT to make traditional practices easier, using ICT themselves rather than letting their students use, and this way they try to develop their productivity. These findings can be interpreted as that, most of the pre-service teachers are at 2 (Adoption), and few are at 1(Entry) level. Some of the statements of the participants in this regard are as follows:

"I don't have much experience in technology use, however I think I will prefer to use a computer to write something, rather than writing it with hand. Additionally, I may write the correspondences demanded by school management, and some letters to the parents with computers. I can ask for help from other teachers, if I have problems with the computer... I don't think I can help my students with the computer. I can only help myself in this. I can ask another teacher who is good with computers to teach my students... Because I don't have knowledge of the subject, I won't assign my students homework that requires technology use. Maybe, they can use the Internet. However, I don't think all Internet sources are reliable."

Almost half of the responses of the same pre-service teachers for the same dimension after the experimental procedure were that ICT is for making traditional practices easier in association with the curriculum (Table 7). Additionally, according to post-interviews, some pre-service teachers considered ICT for personal use and developing their productivity, yet very few teachers provided responses in this direction compared to pre-interviews. Moreover, it was observed that after the experimental procedure, pre-service teachers started using ICT for presentations, as resources and for developing learning purposes.

Considering the interpretations provided above, in terms of their perspectives related to the place and purpose of ICT in teaching processes, most of the experiment group students' integration levels increased to 3 (Adaptation) and 2 (Adoption) for a fewer number of participants after the experimental procedure, with one pre-service teacher at 4 (Appropriation) and one at 1 (Entry) level. This finding indicates that after the experimental procedure, experiment group pre-service teachers' integration levels in terms of their perspectives of the place and purpose of ICT in teaching process increased. This finding can be exemplified with the following quotation.

"I already think that I can make some things easier with the help of technology. For instance, I can provide a more visual presentation for a subject with Power Point... I think it can make presentations easier. I can enable my students' understanding by inserting visuals from the Internet to my presentations... I think watching short films on the subject 
can be effective... I believe I can teach better with electronic resources. These sources are both more economic and more accessible."

Another finding presented in Table 7 is that, control group pre-service teachers provided similar responses for the place and purpose of ICT in teaching processes with experiment group students during the pre-interviews. Like experiment group pre-service teachers, control group pre-service teachers considered the purpose of ICT as making traditional practices easier, and increasing their own productivity. This findings shows that most of the control group pre-service teachers' estimated integration levels were 2 (Adoption), and 1(Entry) for fewer participants. Additionally, data obtained with post-interviews presented in Table 7 show that there weren't many changes in control group pre-service teachers' estimated integration levels, and aforementioned levels were the same for most. A quotation supporting this finding is as follows:

"For me, technology is a tool that makes things easier and more economic. Writing something on the computer would be faster. Additionally, I can help my students with their work with the computer. However, I believe I will mostly use computers not during the classes but before the classes for preparation."

Before and after the experimental procedure, interviews were done with 9 experiment group and 10 control group pre-service teachers selected randomly before the experimental procedure, and the data explaining the estimated integration levels related to the role and efficacy of the pre-service teachers in the in the process of ICT integration are presented in Table 8.

Table 8. Estimated ICT integration levels of pre-service teachers in terms of the role of pre-service teachers in ICT integration process

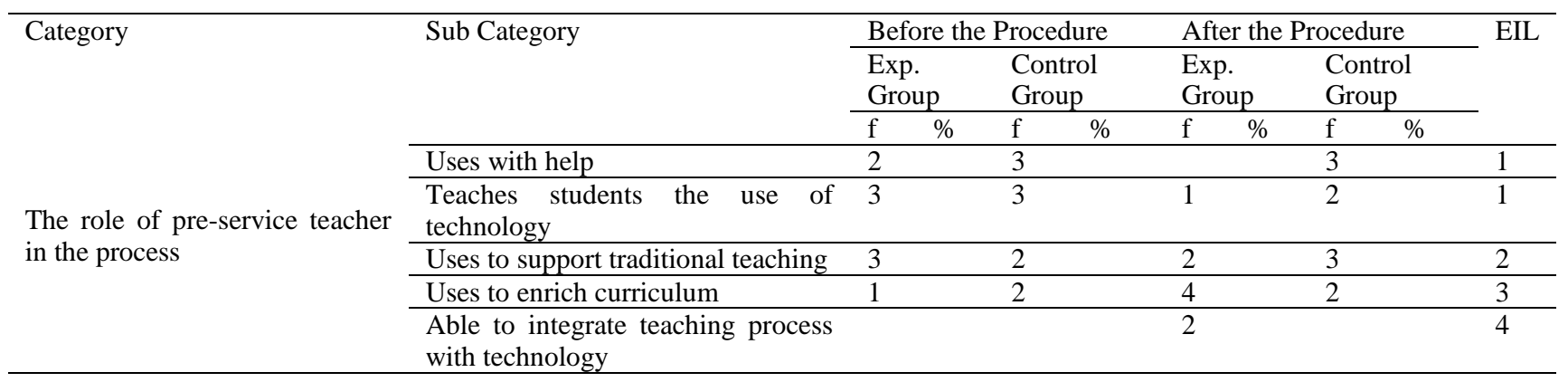

EIL: Estimated integration level (1: Entry; 2: Adoption; 3: Adaptation; 4: Appropriation; 5: Invention)

Findings obtained from pre-interviews, presented in Table 8 , related the role of pre-service teachers in the ICT integration process show that the participants prefer using technology to make traditional practices easier, and receiving help from others to teach technology use to their students. These findings can be interpreted as that, most of the pre-service teachers are at 1(Entry), and some are at 2 (Adoption) level. Some of the statements of the participants in this regard are as follows:

"I think the use of technology in the classes is a supporting element. The learning will be better if I support the lesson with technology... My students should learn to use technology. This has many benefits. The most important of these is time. Today, time is the most valuable source... I think I will ask for help from technology teacher, as I am not very competent. I think I can ask help for both myself and my students. "

There are distinctive differences between the responses of the same pre-service teachers given in the post-interview for the same dimension (Table 8). The most distinctive difference is that, most repeated integration level for pre-interviews-1(Entry) was the least frequent level with the post-interviews. Another difference was that 4 (Appropriation) level wasn't found with pre-interviews, but found with post-interviews; and there was a distinctive increase in 3 (Adaptation) level. These findings show that experimental procedure affected pre-service teachers' integration levels positively. According to post-interviews, more than half of the pre-service teachers can use ICT in a way to enrich curriculum, and integrate teaching processes with technology (Table 6).

Another finding presented in Table 6 is that, control group pre-service teachers provided similar responses for the role of pre-service teachers in the integration of ICT, with experiment group students during the pre-interviews. Like experiment group pre-service teachers, control group pre-service teachers considered the role of pre-service teachers as supporting traditional practices, and preferred receiving support in the process. This finding shows that most of the control group pre-service teachers' estimated integration levels were 1(Entry) and 2 (Adoption) for fewer. Additionally, data obtained with post-interviews presented in Table 8 show that there weren't many changes in control group pre-service teachers' estimated integration levels, and aforementioned levels were the same for most. A quotation supporting this finding is as follows: 
"I prefer using technology during classes. I can make the subject I teach more concrete with the help of technology. Additionally, students can also use technology for some activities. For instance, I can make them write stories on the computer or different story activities. For these activities, we should go to the computer laboratory and the computer teacher should teach some things to students like friend. Actually, I can do that too, but the other way would be better."

\section{Conclusions and Discussion}

For the present research, which studied the effects of information and communication technologies assisted project based learning practices on pre-service classroom teachers' perceptions related to the integration of ICT with teaching environments within the scope of "Turkish Language Teaching" and "Mathematics Teaching I" courses, ICT assisted project based learning practices were conducted on experiment group for 12 weeks, while the control group continued the process projected in the Classroom Teaching $3^{\text {rd }}$ grade undergraduate program. The most important limitation of the present research can be considered as the inability to control the processes implemented in programs other than the experiment and control groups. The level and frequency of the use of ICT in other courses and out of the school by pre-service teachers during the experimental procedures are unknown. Accordingly, ICT experiences out of the 12-week programs were accepted equal for both groups. The findings obtained with the measurements taken during the experimental procedure as follows:

There weren't any statistically significant differences between experiment and control group participants in terms of their scores in ICTSEPS and ICTAS scales pre-test implementations. In other words, experiment and control group pre-service teachers were equal in terms of their ICT attitudes and ICT self-efficacy perceptions before the experimental procedure. The scores from these scales refer to the level of ICT attitude and self-efficacy perceptions of the individuals. According to this presumption, and the ICTSEPS and ICTAS scales pre-test score averages of the pre-service teachers in experiment and control groups, the averages for these scores are distributed around $50 \%$ of the maximum scores from the scale. Therefore, we can infer that ICT attitude and ICT self-efficacy perceptions of pre-service teachers are medium level for both groups. This finding is also important in terms of defining the work-group of the present research. Accordingly, the present research was conducted on two groups of equal ICT attitude and ICT self-efficacy perceptions.

Statistically significant differences were found between experiment and control group students in terms of their ICTSEPS and ICTAS post-test scores, in favour of the experiment group. In other words, ICT assisted project based learning approach conducted with experiment group affected pre-service teachers' ICT attitudes and ICT self-efficacy perceptions more positively than the practices applied with control group. The significant effect stated in this finding is considered that it can be limited to ICT assisted project based learning applications carried in "Turkish Language Teaching" and "Mathematics Teaching I" courses. For this reason, the investigation of the efficacy of the applications on other courses of pre-service teachers is considered as important. ICT attitude and self-efficacy perception as a whole for a teaching program consisting of different course can be investigated with further similar studies.

In addition to these measurements, interviews were conducted with the participants selected from experiment and control groups, before and after the experimental procedures. According to the interviews done before the experimental procedures, most of the experiment group pre-service teachers' estimated integration levels were 2 (Adoption), and 1(Entry) for fewer of them. After the experimental procedures, most of the experiment group pre-service teachers' estimated integration levels were 3 (Adaptation), and 2 (Adoption) for less of them, with one pre-service teacher each with 4 (Appropriation) and 1 (Entry) level. These findings indicate that, experiment group pre-service teachers' estimated integration levels in terms of the place and purpose of ICT in the teaching process increased with the experimental procedure.

The findings obtained with the pre-interviews with the control group pre-service teachers showed that estimated integration levels in terms of the place and purpose of ICT in the teaching process were 2 (Adoption) for most, and 1(Entry) for fewer of the control group students. According to the data obtained with post-interviews, there wasn't much change in control group pre-service teachers' estimated integration levels.

For the role of pre-service teacher in ICT integration process, experiment group pre-service teachers' estimated integration levels were 1(Entry) for most, and 2 (Adoption) for fewer of the experiment group students. After the experimental procedures, there were significant changes in the same pre-service teachers' responses for the same dimension (Table 6). The most distinctive difference is that, most repeated integration level for pre-interviews-1(Entry) was the least frequent level with the post-interviews. Another difference was that 4 (Appropriation) level wasn't found with pre-interviews, but found with post-interviews; and there was a distinctive increase in 3 (Adaptation) level. These findings show that experimental procedure affected pre-service teachers' integration levels positively.

Control group pre-service teachers provided similar responses for the role of pre-service teachers in the integration of ICT, with experiment group students during the pre-interviews. The findings showed that most of the control group pre-service teachers' estimated integration levels were 1(Entry) and 2 (Adoption) for fewer of the participants. 
Additionally, data obtained with post-interviews showed that there weren't many changes in control group pre-service teachers' estimated integration levels, and aforementioned levels were the same for most.

The findings presented above can be discusses in some dimensions. First is based on the comparison of the theoretical structure and findings of the present research. The related literature suggests that attitudes towards ICT and ICT self-efficacy perception together form the estimated ICT integration levels (Sung, 2007). According to the quantitative findings obtained in the present research, ICT assisted project based learning practices conducted with the experiment group were more effective on pre-service teachers' ICT attitudes and ICT self-efficacy perceptions than the practices conducted with the control group. Qualitative findings similarly show that experimental procedures conducted in the present research had positive effects on pre-service teachers' estimated integration levels. These show that the findings of the present research are in agreement with the related literature, which indicate construct validity in a sense (Cornelius-White, 2007).

The related literature also suggests that for a successful integration of ICT with education, an agreement between technology and teachers is required (Marcinkiewicz, 1993). From this perspective, ICT assisted project based learning practices can be considered to provide this agreement. These practices affect pre-service teachers' ICT self-efficacy and attitudes, and therefore increase their ICT integration levels.

Before the experimental procedure, it was observed that pre-service teachers had low levels of ICT attitudes and ICT self-efficacy perceptions and accordingly medium ICT integration levels. This finding is also in agreement with the related literature. Roblyer (2002) reported that many pre-service teachers had very little computer knowledge and their positive attitudes towards the use of ICT in classroom environments were weak when they started their education at universities.

Finally, the related literature claims that the most important factor affecting pre-service teachers' ICT integration levels is the role models they encounter during their education lives. If pre-service teachers cannot have good role models in this sense, they fail in technology integration during education-teaching processes (Breen et. al., 2001; Iding et al., 2002). It can be claimed that ICT assisted project based practices prepared by the pre-service teachers within the scope of the present research provided the participants with good models for technology integration in terms of both product and process. We can claim that ICT assisted project based learning practices conducted within the scope of the present research can provide pre-service teachers with various models as these practices provide pre-service teachers with opportunities to transform classroom environments from traditional teacher centred environments to student centred environments and create environments for sharing and cooperation (Papanastasiou \& Angeli, 2008).

\section{References}

Alberta Learning (2002). Information communication and technology [online]. [cited 11 September 2016]. http://www.learning.gov.ab.ca/k_12/ curriculum/bySubject/ict/>

Bandura, A. (1986). Social Foundations of Thought and Action: A Social Cognitive Theory. New Jersey: Prentice-Hall.

Baylor, A. L., \& Ritchie, D. (2002). What factors facilitate teacher skill, teacher morale, and perceived student learning in technology-using classrooms?. Computers and Education, 39, 395-414. https://doi.org/10.1016/S0360-1315(02)00075-1

Beck, J., Czerniak, C. H., \& Lumpe, A. (2000). An exploratory study of teachers' beliefs regarding the implementation of constructivism in their classrooms. Journal of Science Teacher Education, 11(4), 323-343. https://doi.org/10.1023/A:1009481115135

Bielefeldt, T. (2001). Technology in Teacher Education. Journal of Computing in Teacher Education, 17(4), 4-15.

Breen, R., Lindsay, R., Jenkins, A., \& Smith, P. (2001). The role of information and communication Technologies in a university learning environment. Studies in Higher Education, 26(1), 95-114. https://doi.org/10.1080/03075070123233

Cassidy, S., \& Eachus, P. (2002). Developing the computer user self-efficacy (CUSE) scale: Investigating the relationship between computer self-efficacy, gender and experience with computers. Journal of Educational Computing Research, 26, 133-153. https://doi.org/10.2190/JGJR-0KVL-HRF7-GCNV

CEO Forum on Education and Technology (1999). School Technology and Readiness Report on Professional Development: A link to better learning, Retrieved from http://www.ceoforum.org/reports.cfm

Cornelius-White, J. (2007). Learner-centered teacher-student relationships are effective: A meta-analysis. Review of Educational Research, 77(1), 113-143. https://doi.org/10.3102/003465430298563

Creswell, J. W., \& Plano-Clark, V. L. (2007). Designing and conducting mixed methods research. Thousand Oaks, CA: 
SAGE Publications.

Doering, A., Hughes, J., \& Huffman, D. (2003). Pre-service teachers: Are we thinking with technology?. Journal of Research on Technology in Education, 35(3), 342-361. https://doi.org/10.1080/15391523.2003.10782390

Donnelly, R., \& Fitzmaurice, M. (2005). Collaborative project-based learning and problem-based learning in higher education: A consideration of tutor and student roles in learner-focused strategies. Retrieved from http://www.aishe.org/ readings/2005-1/donnelley-fitzmauricecollaborative-project-based-learning.html

Ekici, E., Ekici, F. T., \& Kara, I. (2012). Validity and Reliability Study of ICT Self-Efficacy Perception Scale for Teachers. Pamukkale University Journal of Education, 31(1), 53-65.

Fishbein, M., \& Ajzen, I. (1975). Belief, attitude, intention, and behaviour: An introduction to theory and research. Reading, MA: Addison-Wesley.

Galanouli, D., \& McNair, V. (2001). Students' perceptions of ICT-related support in teaching placements, Journal of Computer Assisted Learning, 17, 396-408. https://doi.org/10.1046/j.0266-4909.2001.00196.x

Godfrey, C. (2001). Computers in school: Changing technologies. Australian Educational Computing, 16(2), 14-17.

Hismanoglu, M., \& Hismanoglu, S. (2011). Attitude of English Teacher Candidates toward ICT. E-international Journal ou Educational Research, 2(2), 17-29.

Iding, M., Crosby, M. E., \& Speitel, T. (2002). Teachers and technology: Beliefs and practices. Journal of Instructional Media, 29(2), 153-170.

Jimoyiannis, A., \& Komis, V. (2007). Examining teachers' beliefs about ICT in education: Implications of a teacher preparation programme. Teacher Development, 11(2), 149-173. https://doi.org/10.1080/13664530701414779

Krueger, K., Hansen, L., \& Smaldino, S. (2000). Pre-service teacher technology competencies: A model for preparing teachers of tomorrow to use technology. Tech. Trends, 44(3), 47-50. https://doi.org/10.1007/BF02778227

La Velle, L. B., McFarlane, A., \& Brawn, R. (2003). Knowledge transformation through ICT in science education: A case study in teacher-driven curriculum development. British Journal of Educational Technology, 34(2), 183-199. https://doi.org/10.1111/1467-8535.00319

Magliaro, J., \& Ezeife, A. N. (2007). Pre-service teachers' preparedness to integrate computer technology into the curriculum. Canadian Journal of Learning and Technology, 33, 95-111. Retrieved December 15, 2016, from http://www.cjlt.ca/index.php /cjlt/article/view/163/153

Marcinkiewicz, H. R. (1993). Computers and teachers: Factors influencing computer use in the classroom. Journal of Research on Computing in Education, 26, 220-237. https://doi.org/10.1080/08886504.1993.10782088

Moursund, D, (2002). Project Based Learning Using Information Technology. Eugene, OREGON: ISTE,

Mumtaz, S. (2000). Factors Effecting Teachers Ues of Information and Communications Technology: a review of the literature. Journal of Information Technology for Teacher Education, 9(3), 319-341.

https://doi.org/10.1080/14759390000200096

OECD. (2006). Glossary of Statistical Terms: Information, Communication Technology (ICT) sector. 05.11.2016; http://stats.oecd.org/glossary/detail.asp?ID=3038

Papanastasiou, E. C., \& Angeli, C. (2008). Evaluating the use of ICT in education: Psychometric properties of the survey of factors affecting teachers teaching with technology (SFA-T3). Educational Technology \& Society, 11(1), 69-86.

Roblyer, M. D. (2002). Integrating Educational Technology into Teaching (3rd ed.). Upper Saddle River, NJ: Prentice Hall.

Simpson, J. (2010). Integrating project-based learning in an English language tourism classroom in a Thai university. (P.hd Thesis), Australian Catholic University, Sydney.

Steckler, A., McLeroy, K. R., Goodman, R. M., Bird, S. T., \& McCormick, L. (1992). Toward integrating qualitative and quantitative methods: An introduction. Health Education Quarterly, 19, 1-8. https://doi.org/10.1177/109019819201900101

Sung, Y. K. (2007). Are pre-service teachers constructivists in the constructivist teacher education program? Korean Journal of Educational Policy, 4(1), 9-24.

Todman, J. (2000). Gender Differences in Computer Anxiety among University Entrants Since 1992, Computers \& Education, 34, 27-35. https://doi.org/10.1016/S0360-1315(99)00036-6 
Toledo, C. (2005). A five-stage model of computer technology integration into teacher education curriculum. Contemporary Issues in Technology and Teacher Education, 5(2), 177-191.

Visser, S., \& Jain, M. (1997). Towards building open learning communities: re-contextualising teachers and learners, in D. Passey and B. Samways (eds.) Information Technology: supporting change through teacher education, Chapman \& Hall, London. https://doi.org/10.1007/978-0-387-35081-3_2

Wang, L., Ertmer, A. P., \& Newby, J. T. (2004). Increasing pre-service teachers' self-efficacy beliefs for technology integration. Journal of Research on Technology in Education, 36(3), 231-250.

https://doi.org/10.1080/15391523.2004.10782414

Wen, J. R., \& Shih, W. L. (2008). Exploring the information literacy competence standards for elementary and high school teachers. Computers \& Education, 50(3), 787-806. https://doi.org/10.1016/j.compedu.2006.08.011

Willis, E. M., \& Montes, L. S. (2002). Does requiring a technology course in pre-service teacher education affect student teacher's technology use in the classroom? Journal of Computing in Teacher Education, 18(3), 76-80.

\section{Copyrights}

Copyright for this article is retained by the author(s), with first publication rights granted to the journal.

This is an open-access article distributed under the terms and conditions of the Creative Commons Attribution license which permits unrestricted use, distribution, and reproduction in any medium, provided the original work is properly cited. 